\title{
Saints, Poets, and Rubber Ducks: Crafting the Sacred at St Nectan's Glen
}

\author{
Ceri Houlbrook
}

\begin{abstract}
This paper focuses on St Nectan's Glen, Cornwall, where layers of ritual deposition imply a long history of spiritual significance - an implication that is debunked by a diachronic examination of the site, which reveals a relatively recent, and conscious, crafting of the sacred.
\end{abstract}

\section{St Nectan's Glen: The Deposits}

The rubber duck is just one of many deposits at St Nectan's Kieve, Cornwall. ${ }^{1}$ Here the River Trevillet, having run tranquilly through the woodland of St Nectan's Glen, becomes a sixtyfoot waterfall. This cascades down into a surprisingly placid pool below, enveloped by granite cliffs and a rocky shore, which are bedecked with a myriad of deposits, of which the rubber duck is only one example (Figure 1).

Candles, some bearing Christian imagery, sit amidst scattered coins, beaded bracelets, hair accessories, and various unique deposits: an owl-shaped purse, a pair of wooden mushrooms, a water flask, and a miniature model of a Mayan pyramid, to name only some (Figure 2). Pieces of slate - hundreds of them - lean up against the cliff faces, their surfaces adorned with scratched initials, names, messages, Celtic symbols, even painted pictures. Others have been piled on top of each other, in or throughout the water, forming what are known in Cornwall as 'fairy stacks'. The surrounding trees and foliage are festooned with brightly-coloured ribbons, frayed strips of cloth, hair bobbles, jewellery, shoelaces, key-rings, pendants, a prism, and a smiley-faced car air-freshener. One branch is tied with a lock of somebody's hair; another has a Polo mint slipped onto it; while another is affixed with a laminated photograph of a man, the words 'well, hello there' written beneath. A plastic wallet hangs from another, containing the photograph of a dog named 'Ollie', accompanied by the words 'I miss u sooo much ....'.

Propped up against one cliff-face, sloping at a narrow gradient down into the water of the pool, is a coin-tree (Figure 3): a hardwood log, $850 \mathrm{~cm}$ in length, embedded with over four thousand coins. ${ }^{2}$ The majority of the coins, which run in neat longitudinal lines with the grain of the bark, are one penny and two pence pieces, but there are some higher denominations, including four fifty pence pieces and two one pound coins. Along with the coins, the log has also been embedded with three plastic tokens (one from the Sealife Centre), a Hobgoblin beer bottle cap, a key-ring, a piece of green aventurine, and a couple of ribbons, held in place by coins. ${ }^{3}$

St Nectan's Glen is clearly a melting pot of various depositional practices, some boasting long histories - the deposition of coins, candles, hair, rags - and others entirely novel, such as the rubber duck and the Polo mint. Not only was the diversity of deposits noteworthy, so too were their quantities. Unfortunately, while the author recorded every item embedded into the coin-tree, no systematic attempt was made to catalogue each deposit at the site, but their numbers certainly reached the thousands. If each individual deposit signifies an individual depositor, more or less, then the material evidence of St Nectan's Glen attests to a significant - and significantly diverse - set of people who have considered it appropriate to deposit objects at this site. 
This would suggest that St Nectan's Glen is of ritual and spiritual significance; what one might call a sacred site, following the Oxford English Dictionary (2015) definition of 'sacred': 'Dedicated, set apart, exclusively appropriated to some person or some special purpose' (emphasis in original). Moreover, judging by the dense layers of deposition and the name of the glen itself - implying a connection with the fifth-century St Nectan - the evidence would suggest that it has been a sacred site for quite some time.

\section{Sacred Sites}

There are innumerable such sites throughout the British Isles; natural spaces that became sacred places - and maintain themselves as such in contemporary times - through their association with historical and religious figures. Isle Maree in the Northwest Highlands of Scotland is one such site. Here a coin-tree, containing coins dating from 1897 to 2009, along with a variety of other deposits - jewellery, hair accessories, ribbons, candles - mark the spot once occupied by the holy well of St Maree (also known as Maelrubha), who purportedly built his hermitage on the island in the late seventh or early eighth century AD (Houlbrook 2015b). ${ }^{4}$

In Fore, County Westmeath, in Ireland, a water-filled stone vat and large ash tree are bedecked with all manner of items - from the more traditional ribbons and coins to the less traditional socks, toothbrushes, and airline boarding passes - because of the site's association with St Feichin and his purported healing powers (Harbison 1991, 229; Rees 2003, 26-27; Healy 2006, 71-74). Likewise in Clonenagh, County Laois, a sycamore is subject to contemporary deposition (largely coins) because of its connection to a nearby well venerated for its association with the sixth- or seventh-century St Fintan (Roe 1939, 27-28; Harbison 1991, 231-33; Morton 1998, 195; Simon 2000, 27-28). The histories of such sites tend to follow similar patterns: holy wells, which may have possessed pre-Christian significance, ${ }^{5}$ are appropriated by Christian saints, imbued with curative properties, and - either continuously or intermittently - are perceived as sacred sites throughout history to the present day, where depositors may adapt the depositional practices for the sake of contemporary relevance or convenience (Houlbrook 2015b).

It is easy to imagine that the history of St Nectan's Glen followed a similar pattern; that the site is considered 'sacred' because of its association with the fifth- or sixth-century St Nectan. Indeed, the site's website supports this image, reporting that:

The sixth-century Saint Nectan is believed to have sited his hermitage above the waterfall. According to legend, Saint Nectan rang a silver bell in times of stormy weather to warn shipping of the perils of the rocks at the mouth of the Rocky Valley. Saint Nectan's Kieve is to some a sacred place. (http://www.stnectansglen.co.uk/history/)

This image, however, is inaccurate. By providing a chronology of the site this article will demonstrate that, contrary to first impressions, St Nectan's Glen has only a very short history of being ritually or spiritually significant, and that its construction as a sacred site is the product of a relatively recent, and deliberate, process.

\section{St Nectan: What's in a Name?}

Names say a great deal. The naming of a site is important - one might say vital - in colouring our perceptions of it; as Derrida observes, "when a name comes, it immediately says more than the name' $(1995,89)$. It is, according to Susan Pearce, a 'medium for the communication of information' $(1992,123)$, and not only does a name reveal how we perceive an object, 
being, or place, it also influences it (Lindsay and Norman 1972, 438). It is therefore not much of a stretch to claim that St Nectan's Glen is named after St Nectan (who is interchangeably referred to as St Nighton (Butler 1956, 565)), and that most people who read or hear its name make the same deduction.

Relatively little is known about the glen's namesake, and most of our information accurate or not - comes from a series of (probably) twelfth-century records written anonymously at or for the church of Hartland in Devon, where St Nectan is most strongly associated (Baring-Gould and Fisher 1913, 1-2; John 1981, 47; Orme 2000, 197-200). These records recount the saint's life, telling of how he was the eldest of twenty-four sons and daughters of Broccannus (Welsh Brychan), a legendary prince of Brycheiniog in Wales. Having crossed the Bristol Channel, Nectan settled in a hermitage at Stoke in Hartland, which became his principal cult centre, while the church at Welcombe, Devon, was also dedicated to him. Nectan is said to have been martyred on 17 June (year unknown) when two robbers, whom he had sought to convert to Christianity, beheaded him; whereupon Nectan picked up his head and carried it back to his hermitage. His body was apparently rediscovered in the tenth or eleventh century, when it was enshrined within the church of Hartland (Orme 2000, 198).

It would not be a stretch to claim that St Nectan, most strongly associated with Devon, crossed into Cornwall at some point in his life, and his association with St Nectan's Glen is clear. As the glen's visitor website claims, St Nectan is believed to have sited his hermitage within the glen, specifically above the waterfall, and this belief is testified to in earlier sources. In Peter Redgrove's novel The Glass Cottage (1975), the author describes how 'St. Nectan's Hermitage' was located in the glen, and this was 'where the Cornish Saint had lived and prayed and healed' $(1975,216)$. In 2008, J. Gordon Melton simply recounts the life of St Nectan in his encyclopedia entry on the glen: 'he lived by himself and built a small church near the spring' $(2008,287)$. Clearly the association between St Nectan's Glen and St Nectan, intrinsic in the name, is a primary contributing factor to perceptions of the site as ritually or spiritually significant.

However, it must be remembered that language is malleable and names are flexible. They are not static, and can be changed depending upon who is speaking, when, and to whom. It is easy to assume that because St Nectan's Glen is now called St Nectan's Glen, it has always been known as such, but this is an erroneous assumption. In fact, it is unlikely that St Nectan had any connection at all with the glen which bears his name, a theory strongly posited by antiquary and topographer Sidney Joseph Madge, who dedicated a monograph to the history of the site (1950). While St Nectan was venerated in Cornwall, such as at Launceton, and at Lostwithiel and Newlyn where chapels were dedicated in his honour under his alternative name St Nighton (Butler 1956, 565), the saint's Life makes no mention of his having settled in Cornwall, let alone at the site concerned.

The first known reference to this site was made in the 1799 edition of Thomas Gray's Traveller's Companion, in which it was not described as 'St Nectan's Glen', but as 'Nathan's Cave' (Gray 1799, 15). 'Cave' may have been a misunderstanding, or variant spelling, of the Cornish term 'kieve', which refers to the bowl-shaped basin at the foot of the waterfall. As for 'Nathan', Madge believes that this name may simply have been connected to two graves in the nearby churchyard of Tintagel: Nathan Williams, 1712, and Nathan Cock, 1762 (1950, 32). Perhaps these were figures of prominence in the area, or had named after one. Either way, in the absence of a local saint by the name of Nathan, it seems likely that the glen's early name was entirely secular. Evidently it did not remain so. However, there was no one point at which the site's name shifted abruptly from 'Nathan's Cave' to 'St Nectan's Kieve'. Rather, it underwent various changes before reaching its current incarnation, and this chain of re-articulations is most illustratively presented in the work of poet Robert Stephen Hawker. 


\section{Robert Stephen Hawker: A Poet's Appropriation}

Robert Hawker was a nineteenth-century poet, vicar, and antiquarian, born in Plymouth in 1803 (Hutton 2004, 1). He lived the majority of his life in Cornwall, as vicar of Morwenstow, and is so well known in the county that the stretch of coastline on which he resided is referred to locally as 'Hawker Country' (Hutton 2004, iv). Patrick Hutton describes him as a man 'known for his eccentricity, but [who] deserves to be further renowned as poet, mystic and priest' $(2004, v)$. His poetry, which was not widely published and which Hutton laments as 'grievously underrated' $(2004,222)$, reflects a great interest in the history of his home county and the legends attached to it. In the preface to his collection of poems, Records of the Western Shore, he writes that:

The simple legends connected with the wild and singular scenery of my own County, appear to me not undeserving of record. These, which I have published were related to me, in the course of my solitary ramblings in the West. They were 'done into verse' also, during these my walks and rides $(1832,3)$

Arthurian tales interested him, as can be seen in his poem The Quest of the Sangraal (1864), but he was particularly attracted to stories concerning local saints. As Sabine Baring-Gould aptly notes in his biography of Hawker: 'On looking at the map of Cornwall, one is surprised to see it studded with the names of saints, of whom one knows nothing' $(1899,24)$. These largely fifth- and sixth-century saints, who were either native to Cornwall, travelled there from Ireland or Wales, or were simply associated with a site through popular imagination rather than historic fact, left their names on the landscape. In Hawker's poem 'The Cornish Fathers' (1846), the poet observes that these saints 'had their lodges in the wilderness, / Or built their cells beside the shadowy sea; And there they dwelt with angels like a dream' (1846, vi). According to Hawker, Nectan was one such saint, dwelling above a waterfall in a wooded glen near Tintagel. Hawker had previously described the structure that he would later associate with Nectan as 'four walls matted with ivy and overgrown by gorse' situated on 'the brink of the rock from whence the stream leaps into the glen below' $(1832,31)$. This is undoubtedly a description of the modern-day St Nectan's Glen. It is unsurprising that Hawker should have been familiar with this site, a mere thirty or so miles away from his parish in Morwenstow. It was - and still is - undoubtedly a place of natural beauty, and appears to have been admired for this in Hawker's time.

Charles Sandoe Gilbert, in his An Historical Survey of the County of Cornwall, gave the following appreciative description:

The south-east end terminates with a most stupendous waterfall ... which for beauty and singularity, far exceeds the celebrated waterfall at Lydford in Devon . . . . On a near approach to the cascade, the waters are heard falling with a most tremendous crash, the noise of which, reverberated by the adjoining cliffs, strike the spectator with admiration and delight. ... The beauty and solemnity of this charming cascade, is greatly heightened by the solitude of the situation, the grandeur of the rocks, and the numerous wild plants, which shoot out their foliage from the opening fissures. $(1820,586-87)$

Hawker was inspired to pen a poem about the site-inspired, no doubt, by the aesthetic qualities of the waterfall and nearby ruins, but also, purportedly, by the folklore already attached to them. In 1864, Hawker wrote that there was 'a local legend linked with this ruined abode, which was told me on the Spot' $(1864,27)$; a local legend, told to him by an 'Old 
Man' who had, in turn, been told it by 'his Grandsire dead' $(1832,29)$. Hawker claims to have reproduced this legend, this snippet of local folklore, in the poem he published in 1832. This poem, entitled 'The Sisters of the Glen', recounts the tale of two 'ancient' sisters, who mysteriously appeared one day in the glen, their origins unknown. 'Their speech was not in Cornish phrase', reports Hawker; 'Their garb had marks of loftier days' $(1832,29)$. They lived in the glen in the 'reliques of a human cell' until they died, the mystery of who they were and where they had come from left unresolved.

In the first edition of this poem Hawker begins by describing the glen, and his opening line reads, 'It is from Nathan's mossy steep ...' '(1832, 28; emphasis added). This is in keeping with Gray's secular designation of the site as 'Nathan's Cave' (Gray 1799, 15). However, in another publication of the same year, the site was being given saintly associations; in their Cornwall Illustrated, John Allom Britton and Edward Wedlake Brayley referred to it as 'St. Knighton's Kieve' $(1832,15)$. Knighton is probably an alternative spelling to Nighton, a name which was interchangeable with St Nectan (Butler 1956, 565); so by the time Hawker was publishing his poem, the glen was already associated with St Nectan.

Three years later Letitia Elizabeth Landon published a poem entitled 'St. Knighton's Kieve' (1838 [1835], 291); in this, the kieve is the site of a 'gloomy well' which contains magical treasure in the form of a 'golden cup' carved by the fairies. Seven years after this, a painting by Irish artist Daniel Maclise showing a girl standing at a waterfall was entitled Waterfall at St Nighton's Kieve, near Tintagel (1842). ${ }^{6}$

It did not take Hawker long to adopt this saintly association, albeit drawing on a different saint. When he republished his poem fourteen years after the original in Echoes from Old Cornwall (1846), the title had been altered to 'The Sisters of Glen-Neot'. The glen's name had thus been changed to foster an association with the ninth-century St Neot, said to have been a monk of Glastonbury Abbey who, seeking a life of solitude, later lived in a hermitage in Cornwall (John 1981, 47-48) - presumably, in Hawker's belief, in the 'human cell' later inhabited by the sisters of his poem. The opening line of this slightly altered poem thus reads, 'It is from Neot's sainted steep . . .' (1846, 72; emphasis added).

The site did not retain its link with St Neot for long. In Hawker's 1864 reprint of the poem, the glen's name had been changed once more, referring back to the site's earlier association with Nighton/Knighton: the poem, now entitled 'Saint Nectan's Kieve', opened with, 'It is from Nectan's mossy Steep . . ' (1864, 27; emphasis added). Hawker claims, in his accompanying note to the 1864 version of the poem, that the waterfall 'has borne for Ten Centuries the Name of St. Nectan's Kieve' $(1864,27)$ - an ironic statement considering that a mere eighteen years before he had referred to it as 'Glen-Neot' (Hawker 1846).

Over a period of thirty-two years, therefore, both the name of the glen and its saintly associations had changed: from Nathan, to St Knighton, to St Neot, to St Nectan. While this process of change was not exclusively the result of Hawker's poem, as Madge opines (1950: 64), his work no doubt contributed to the site's association with St Nectan, which appears to have been accepted by the latter half of the nineteenth century. In Robert Hunt's Popular Romances of the West of England (1865, 27-33), for example, the site is described as 'St. Nectan's Kieve' - although Hunt does acknowledge in a footnote that it is 'called indifferently Nectan, Nighton, or Knighton's Kieve' (1908 [1865], 279). However, by 1882 it was named only as 'St. Nectan's Kieve' in Mary Elizabeth Braddon's novel Mount Royal $(1882,76)$, and has continued to be referred to as such throughout the twentieth and twentyfirst centuries.

Was this final transferral to St Nectan precipitated by Hawker? Hawker himself admitted to some poetic license, claiming in the note to the latest version of his poem in Cornish Ballads: 'I invented it myself' $(1869,9)$. His adaptation may have stemmed from a change in personal circumstance. While penning the first two versions of this poem, Hawker 
had been the vicar of Morwenstow, but in 1851 he was given also the parish of Welcombe, just over the county border into Devon. Interestingly, Hawker's new church was dedicated to St Nectan - purportedly because the saint was said to have lived in a cell on the site of the church (Baring-Gould 1899, 148), but more likely because Welcombe was a daughter church of Hartland, St Nectan's cult centre. Was Hawker's adaptation of the glen's name, therefore, a result of the poet's newly acquired parish?

\section{Constructing the Hermitage}

St Nectan's hermitage, widely accredited to have been built above the waterfall, appears to have been as romanticized over time as the glen itself. Despite Hawker's having described it in 1832 as simply 'four walls matted with ivy and overgrown with gorse' $(1832,31)$, he ascribes it Christian origins in his 1864 edition: 'the outline of an Oratory, or the Reliques of a Hermitage' $(1864,27)$. Already in 1842 Cyrus Redding had described the structure as 'four walls covered with vegetation, the roofless remnant of the abode of some hermit in times gone by, who resided there to pray for the souls of shipwrecked mariners' $(1842,35)$. While in 1865, Hunt was describing the structure as 'the little chapel of the good St Nectan' (1865, 27 ), suggesting that it had been associated with the saint for some time, whether as a result of Hawker's poetry or not.

Baring-Gould and Fisher, in The Lives of British Saints, are wary of using Hawker as a source in their entry on St Nectan - 'Mr. Hawker was a man of lively imagination, and the story may be merely ben trovato' $(1913,1)$ - but they still accept without question that the structure above the waterfall was connected with St Nectan: 'S. Nighton's (Nectan's) Keive is a waterfall at Trethevy where was his chapel' $(1913,2)$. Later works continue to make this connection between structure and saint. Janet and Colin Bord, for example, claim that Nectan 'lived in a sanctuary above the waterfall' $(1995,132)$.

Madge, however, posits a much more secular purpose for this structure, which he notes 'had no ancient and, above all, no ecclesiastical features' (1950, 59). He claims instead that the structure was an eighteenth-century grotto or pleasure-house built by the owners of the Trevillet estate $(1950,59)$. Indeed, the earliest known reference to this structure, Charles Sandoe Gilbert's Historical Survey of the County of Cornwall (1820), describes it as 'the remains of a small temple, or summer-house, erected most probably, by the family of Wood [owners of the Trevillet estate]. It measures twenty feet six inches by twelve feet, and has one window' $(1820,586-87)$. He then describes the 'gratifying perspective' provided by this window, overlooking the glen, which would probably explain the motives behind building a summer-house at that particular site.

This would not necessarily invalidate the structure's classification as a 'hermitage'. As Gordon Campbell demonstrates in The Hermit in the Garden (2013), there was a trend in the eighteenth century for the grounds of an estate to include an ornamental and secular hermitage, designed for seclusion - and ideally utilized by a resident hermit. The structure in St Nectan's Glen may well, therefore, have been classed as a hermitage; that it was once the hermitage of St Nectan, however, is grossly unlikely. However, the probable secular origins of this structure appear to be little known. Even the organization Historic England seem to have accepted this tradition; on their website PastScape, which catalogues England's archaeological and architectural heritage, there is an entry for the site of this structure (Monument No. 431919), which it describes as the 'alleged site of the Medieval chapel of St Nectan'?

Madge asserts that Hawker "laid the foundation for all the "legends" that have kept poets, guides and tourists busy ever since' $(1950,30)$. While this is not entirely true - the site's association with St Nighton/Nectan appears to pre-date Hawker's work - the poet did 
play a part, alongside other such cultural figures as Landon, Maclise, and Braddon, in perpetuating, and probably precipitating, this gradual conversion of the site's namesake from an unknown Nathan to a Christian saint, and its eighteenth-century summer-house into a hermit's cell. The site's connection with St Nectan is based less on historical fact than on the imaginations of poets, writers, and artists exercising their poetic licenses. Despite this, however, the saint is central to the site's commercial identity.

\section{Folklorismus}

St Nectan's Glen is privately owned. In 2012 it was purchased by Guy Mills and placed under the management of Lawrence 'Loz' Barker. Despite local concern that new ownership would restrict public access, Mills asserted in the Cornish Guardian newspaper in March 2012 his intention to keep the glen 'a place of inward reflection and self-realisation for everyone to enjoy'. ${ }^{8}$ As before the sale, the majority of the glen remains open to the public, while an entry fee is charged for admittance to the waterfall, to reach which visitors must pass through a quaint tea-room and gift shop. With the proceeds contributing to the maintenance of the site, Mills stated his desire to 'achieve a balance between nature conservation, respect for beliefs and expectations of all visitors and the commercial opportunity'- a commercial opportunity which no doubt benefits from the site's saintly association.

On their website, the owners of St Nectan's Glen today recount the belief that St Nectan had built his hermitage in the glen: 'The sixth-century Saint Nectan is believed to have sited his hermitage above the waterfall'. ${ }^{9}$ Whether knowingly or not, site management is thus creating - or in this case, maintaining - a narrative that will appeal to the public and subsequently draw more (paying) visitors. This narrative imbues the site with a greater historical significance than reality may support, and it is not difficult to understand why site management may wish to draw on this significance in their portrayal of the glen. Simply put, people like history. Antony Gormley notes that the 'English national psyche has been a victim of the past, binding us to a reverence for the old things' $(2007,7)$, while David Lowenthal writes of 'nostalgic affliction' $(1985,10)$; an affliction characterized by the high demand for antique shops, vintage clothing, and period dramas.

The story of St Nectan's Glen is certainly not the only British 'tradition' which appears far older than it is. Eric Hobsbawm and Terence Ranger note how many 'traditions' from ceremonies of the British monarchy to Christmas carols - are just some of the many customs 'which appear or claim to be old [but] are often quite recent in origin' $(1983,1)$. A custom will feel more firmly established if it is bestowed with a sense of age; in this way, age authenticates. As Lowenthal asserts, by implying that a site or structure boasts some antiquity, the designation 'lends it status' $(1985,265)$.

The authenticating power of age is well-documented. Cornelius Holtorf and Tim SchadlaHall, writing of 'age-value', clearly demonstrate a perceived inherent connection between age and authenticity $(1999,232)$. Objects wear their patinas as badges of pride because they are viewed as evidence of antiquity, and value is attributed to age, from collectors' items to ordinary, everyday objects which eventually find their way into museum displays simply because of their antiquity (Goffer 1980, 264; Spooner 1986; Macdonald 2002). As Sefryn Penrose observes, 'the older something becomes the more important it tends to be thought' $(2007,13)$. The same applies to sites and their traditions, which appear to be viewed by many as only interesting insofar as they are seasoned.

As folklorist Venetia Newall observes, often what we perceive as a continuation of a tradition actually proves to be a 'deliberately inserted renaissance' $(1987,146)$; customs and stories which may appear old are, in many instances, actually the result of recent and 
conscious invention. Folklore's malleability, so vital to its survival, consequently makes it all the more susceptible to appropriation, modification, and recontextualization (Houlbrook 2015b). 'Traditions' are artificially patinated in order to increase their public appeal, and today this patination is usually motivated by one primary factor: tourism (Zipes 1997, 12).

'Tourism', writes Moya Kneafsey, 'could be seen as a use of landscape as a resource' $(1995,136)$, and with landscapes being intrinsically connected to the identity of a place, it is unsurprising that they are so often drawn upon in tourism as a resource to display that identity. However, landscapes are not static. As Gabriela Muri observes, 'Space is newly constituted ... to the extent that new meanings are attributed to it and experience is structured to support tourist activities' $(2001,61)$. The folklore of a landscape is suitably pliable for this function, and can easily be adapted or manipulated for what Muri terms 'showcase tactics' $(2001,55)$.

Numerous scholars have examined how tourism has impacted and modified folk traditions worldwide. John Creighton, for example, considers the impact 'nostalgia tourism' has on the folk traditions of Japanese rural areas. Muri, focusing on a tourist attraction in the Montafon Valley, Austria, which claims to be the 'world's smallest village', considers how central tourism is to the process of imparting and interpreting folk traditions; while Helaine Silverman studies how archaeological tourism has influenced contemporary constructions of history and traditions in Peru (Creighton 1997; Muri 2001; Silverman 2002).

Newall (1987) offers numerous examples from across Europe of such 'showcase tactics', recounting illustrative anecdotes such as how schoolboys from Inzell, Germany, in 1955, were instructed by their headmaster to build models of 'ghosts' from their local legends out of moss and branches, and to display them at the roadside to 'please summer visitors' (1987, 136). Britain likewise draws on local legends for the sake of tourism. For example, in 1975 the British Tourist Authority produced an information sheet listing the haunted hotels and inns of England and Wales (Newall 1987, 143), while the Dungeon tours of Edinburgh, London, Blackpool, and York recount local horror stories, offering tourists the 'ultimate thrill-filled journey through [the city's] murky past - perfect for a day out during the summer holidays!' 10

These are all examples of the conscious re-utilization of folklore and the deliberate adaptation of tradition, a process coined 'folklorismus' in Germany and adopted by Newall (1987). The site of St Nectan's Glen has been subject to the same process, which has a clear impact on how the public perceive and experience it today.

\section{St Nectan's Glen Today}

St Nectan's Glen remains a place of legend. Bord and Bord wrote in 1995 that the 'lane to the waterfall is said to be haunted', reporting the story of two figures disappearing before somebody's very eyes $(1995,132)$. That these two figures were the pair of women who purportedly buried St Nectan - 'possibly the saint's sisters'- is not explicitly stated, but there does seem to be some connection with Hawker's 'Sisters of the Glen'. The haunted theme is repeated in Ellis's article in Meyn Mamvro: 'His [St. Nectan's] spirit is said to haunt the waterfall to guard it against harm' $(1992,19)$, while in Sheila Bird's Haunted Places of Cornwall the glen is described as a site haunted by chanting monks, piskies (Cornish pixies), and a ghost dog $(2006,34)$. In addition to these narratives - indeed, probably because of them - St Nectan's Glen has become a site of dense deposition.

It was posited above that the masses of deposits at St Nectan's Glen, from candles and ribbons to the rubber duck, imply a 'tradition' of deposition at the site. In particular, the heavily patinated coins embedded into the coin-tree - prematurely worn and weathered due to 
exposure - foster a sense of antiquity. However, although it is unclear when the practice of leaving offerings first began, it was probably no earlier than the 1970s. A scene in Redgrove's novel The Glass Cottage (1975) takes place in St Nectan's Glen, and the author devotes four pages to describing the aesthetic and geological properties of the place in great detail. He does not, however, mention any evidence of deposition at the site - and neither do any earlier sources which describe the glen (Gilbert 1820, 586-87; Hawker 1832, 28-31; Redding 1842, 35-36; Hawker 1846, 72-73; Hawker 1864, 27-29; Madge 1950).

Cheryl Straffon, member of the Cornwall Earth Mysteries Group, reports that she has observed 'offerings' at St Nectan's Glen since the 1980s, when she first started visiting the site regularly, but does not believe that the practice of deposition became prolific until the early twenty-first century (pers. comm., 18 February 2016). Certainly judging by a photograph of the coin-tree which leans against one of the cliff-faces, taken by a visitor in 2006 (Figure 4), the custom of coin insertion does not appear to have been popular in the mid 2000s; this may indicate that this coin-tree does not far pre-date the 2000s. Contrasting this photograph with those taken by the author in 2013 (Figure 3), it is clear that coin density increased greatly over that seven-year period, quantities having at least quadrupled. Of course, the more deposits there are, the more they will attract (Figures 5-6).

This is how innovations are diffused. This is how, for example, the custom of the coin-tree appears to have spread across the British Isles. People witness other people inserting coins into trees and so, taking their cue from their peers and submitting to the "emotional contagion' of their environment; they imitate and insert a coin themselves (Bandura 1977; Hatfield et al. 1994, 2; Houlbrook 2015d). Thus is the nature of accumulation, which Clive Gamble describes as having a 'magnetic-like effect' $(2007,122)$. Assemblages of deposits are self-fulfilling; deposits attract more deposits, often at an exponential rate, and in doing so they construct a sense of the 'sacred' by acting as physical markers of a site's significance.

This appears to have been the process at St Nectan's Glen. Visitors see the deposits left by past visitors and wish to follow suit, contributing to the assemblage of deposits and thus to the construction of the site itself. On the author's visit to the glen in April 2013, several visitors were interviewed, and it quickly became clear that the desire to leave a deposit is motivated by the belief that St Nectan's Glen is a 'sacred' or 'magical' site. One woman asserted that 'you can't come to a place like this and not leave your mark', while another woman compared the leaving of a deposit to 'leaving a part of yourself in a sacred place, like lighting a candle in a church'. The words 'sacred' and 'spiritual' featured heavily; one visitor from Spain described the glen as a 'sacred place'; another visitor, a 'beautiful, spiritual place'; while another described it as 'really special', explaining that she is not ordinarily 'spiritual', but 'it's easy to get carried away in a place like this'.

Not all visitors to the glen respond positively to the practice of deposition. In an article written for Meyn Mamvro - tellingly entitled 'St. Nectan's Kieve Abused' - Shane Gary describes his reaction to the site in 2002:

It looked as though a refuse tip had been scooped up and dropped on the site. Every available branch had been covered in vast quantities of hideous rubbish, we assume trying to pass for clouties ... The rubbish we found garrotting the branches of the Kieve were made up of such things as plastic ribbons, necklaces of plastic beads, plastic and metal key-rings, plastic bags, cigarette lighters on pieces of string, plastic and glass bottles, broken sunglasses, and the list went on . .. There was even a computer printed cartoon figure of a penguin in a plastic A4 sleeve with an empty plastic tissue bag clipped to it with a plastic bulldog clip! One wonders at mentality behind such 'offerings'... (2002, 19) 
St Nectan's Glen has evidently become a contested site, entering the 'ritual litter' debate that has become relatively common at places of historical or spiritual significance (Houlbrook 2015a; Rountree 2006; Wallis and Blain 2003). Whether the coins, ribbons, candles, and rubber duck are classified as offerings or 'hideous rubbish', to use Gary's phrase, is entirely dependent upon the personal or professional perspective of the observer.

For some visitors, the deposits do not seem to detract from their experience of the site. On St Nectan's Glen website in the 'Your Views' section, site manager 'Loz' Barker assures visitors that they will be 'astounded by the natural beauty and amazing feeling given off by the sacred energy of the waterfall' - and this does appear to be the case, judging by many of the visitors' online comments. ${ }^{11}$ One visitor declares that the 'magic is still with me as it always is when I visit there and also helps me with my Spiritual \& Healing work' (August 2012). Nine visitors describe the glen as 'magical' (August 2012, October 2012, January 2013, May 2013, June 2013); another, as a 'beautiful special place', recommending the 'fantastic clensing [sic] energy' of the waterfall (August 2012), while another extols the 'powerful energies given off by this most amazing and mystical of places' (June 2013). It does not seem such a farfetched claim, therefore, as stated in an online article in the West Briton, that St Nectan's Glen is 'reputed to be in the top ten of the most spiritual sites in the country'. ${ }^{12}$

\section{Concluding Remarks}

There can be no disputing that St Nectan's Glen constitutes a sacred space, as a site that has been 'set apart' for 'some special purpose', in keeping with the $O E D$ definition of 'sacred'. Physically it has been set apart, demarcated from the surrounding landscape by layers of deposition, signifying it as a site of ritual or spiritual significance. The coins, ribbons, candles, personalized messages, engraved pieces of slate, and yes, even the rubber duck, all contribute to the construction of the glen as a sacred site in that they evince people's desires to leave offerings there or make their mark on the place. The testimonies of the depositors themselves also demonstrate this, confirming that St Nectan's Glen is perceived as 'special', 'powerful', 'spiritual', 'mystical', and, indeed, 'sacred'.

However, what a diachronic examination of this site demonstrates is that the 'sacred' - indeed, much like the 'secular' - is not an inherent attribute, and neither is it fixed. The 'sacred' is an artificial construction, in this case sparked by the malleability of folklore; precipitated by such things as the imagination of a local writer exercising his poetic license; and perpetuated by commercialization. The glen's natural, aesthetic qualities provided a solid foundation for such a construction, inspiring the attributions and appropriations which would turn Nathan's Cave, an undoubtedly beautiful but secular site, into 'St Nectan's Glen', a sacred space reputed to be one of the most spiritual sites in the country.

\section{Acknowledgements}

I would like to thank my PhD supervisors Tim Insoll and Petra Tjitske Kalshoven for their support and advice throughout my doctoral research and beyond. Many thanks also to Lawrence 'Loz' Barker, Cheryl Straffon, and Sally Daffern for their very helpful correspondences. Particular thanks go to the journal's peer reviewers, one of whom was Jeremy Harte, who provided a wealth of invaluable sources and information for the improvement of this article.

\section{Notes}


1 The term 'kieve' means 'tub', 'vat', or 'cauldron' in Cornish dialect, and refers to the bowlshaped basin at the bottom of the St Nectan's Glen waterfall (Hawker 1836, 36).

${ }^{2}$ For further information and discussion on British coin-trees, see Houlbrook 2014, 2015a, 2015b, 2015c, 2015d.

${ }^{3}$ These observations are taken from the author's visit to the site in April 2013.

${ }^{4}$ These observations are taken from the author's visit to the site in April 2012.

${ }^{5}$ While the theory that holy wells possessed pre-Christian significance is a popular one, it should be noted that scholars such as James Rattue have questioned the extent to which this was the case: 'it is not good enough,' Rattue writes, 'to use paganish ritual as evidence of pagan worship' (1995, 37).

${ }^{6}$ Waterfall at St Nighton's Kieve is currently part of the collections of the Victoria \& Albert Museum in London: http://collections.vam.ac.uk/item/017817/waterfall-at-st-nightons-kieveoil-painting-maclise-daniel/

${ }^{7}$ See http://www.pastscape.org.uk/ (last update February 2016).

8 See http://www.cornishguardian.co.uk/New-owner-vows-sacred-site-St-Nectan-s-Glenopen/story-15516560-detail/story.html. Commercialism at St Nectan's Glen had earlier undergone some criticism in the 1992 issues of Meyn Mamvro: Ancient Stones and Sacred Sites in Cornwall. Robin Ellis opined that 'it would be a tremendous place for meditation - if it wasn't for the café and all the tourists it attracts!' (Ellis 1992,19) - a criticism which elicited a number of responses from later contributors to the magazine, some disagreeing with Ellis, claiming that accessibility necessitates a degree of commercialism (e.g. Laws 1992), and others similarly condemning the commercialization of the site (e.g. Pacsco 1992).

${ }^{9}$ See http://www.st-nectansglen.co.uk/history/.

${ }^{10}$ See, for instance: http://www.thedungeons.com/edinburgh/en/.

${ }^{11}$ All comments posted at http://www.st-nectansglen.co.uk/your-views/.

${ }^{12}$ Article posted 20 April 2011, by 'This Is Cornwall': http://www.westbriton.co.uk/Sale-sparksfear-access-sacred-site/story-11471725-detail/story.html.

\section{List of Illustrations}

Figure 1 - The rubber duck, amidst coins, a ribbon, and a candle at St. Nectan's Glen, 2013 (Photograph by author)

Figure 2 - Various deposits, including a miniature model of a Mayan pyramid and several ribbons, at St. Nectan's Glen, 2013 (Photograph by author)

Figure 3 - The coin-tree of St. Nectan's Glen, 2013 (Photograph by author)

Figure 4 - The coin-tree of St. Nectan's Glen in 2006, above (Photograph by Sally Daffern) contrasted with the coin-tree in 2013, below (Photograph by author)

Figure 5 - Pieces of slate inscribed with names and messages, propped up against the cliff face at St. Nectan's Glen, 2013 (Photograph by author)

Figure 6 - Ribbons and other items attached to the trees at St. Nectan's Glen, 2013 (Photograph by author) 


\section{References Cited}

Bandura, Albert. Social Learning Theory. Englewood Cliffs, NJ: Prentice-Hall, 1977.

Baring-Gould, Sabine. The Vicar of Morwenstow: Being a Life of Stephen Hawker, M.A. London: Methuen, 1899.

Baring-Gould, Sabine, and John Fisher. The Lives of the British Saints. Vol. 4. London: Honourable Society of Cymmrodorion, 1913.

Bird, Sheila. Haunted Places of Cornwall. Newbury: Countryside Books, 2006.

Bord, Janet, and Colin Bord. The Enchanted Land: Myths and Legends of Britain's Landscape. London: Thorsons, 1995.

Braddon, Mary Elizabeth. Mount Royal. London: John \& Robert Maxwell, 1882.

Britton, John Allom and Edward Wedlake Brayley. Devonshire \& Cornwall Illustrated. London: H. Fisher, R. Fisher, \& O. Jackson, 1832.

Butler, Alban. Butler's Lives of the Saints. Edited by H. Thurston. London: Burns \& Oates, 1956.

Campbell, Gordon. The Hermit in the Garden: From Imperial Rome to Ornamental Gnome. Oxford: Oxford University Press, 2013.

Creighton, John. Coins and Power in Late Iron Age Britain. Cambridge: Cambridge University Press, 2000.

Derrida, Jacques. On the Name. Stanford: Stanford University Press, 1995.

Ellis, Robin. 'Serpent Power'. Meyn Mamvro: Ancient Stones and Sacred Sites in Cornwall 17 (Winter/Spring 1992): 18-19.

Gamble, Clive. Origins and Revolutions: Human Identity in Earliest Prehistory. Cambridge: Cambridge University Press, 2007.

Gary, Shane R. 'St. Nectan's Kieve Abused'. Meyn Mamvro: Ancient Stones and Sacred Sites in Cornwall 49 (Autumn 2002): 19.

Gilbert, Charles Sandoe. An Historical Survey of the County of Cornwall: To which is added, A complete heraldry of the same; with numerous engravings. Vol. 3. London: J. Congdon, 1820.

Goffer, Zvi. Archaeological Chemistry: A Sourcebook on the Applications of Chemistry to Archaeology. New York: John Wiley \& Sons, 1980.

Gormley, Antony. 'Foreword'. In Images of Change: An archaeology of England's contemporary landscape, edited by Sefryn Penrose, 7. Swindon: English Heritage, 2007.

Gray, Thomas. The Traveller's Companion, in a Tour through England and Wales; Containing a catalogue of the antiquities, houses, parks, plantations, scenes, and situations, in England and Wales, arranged according to the alphabetical order of the several counties. London: G. Kearsley, 1799.

Harbison, Peter. Pilgrimage in Ireland: The Monuments and the People. Syracuse: Syracuse University Press, 1991. 
Hatfield, Elaine, John T. Cacioppo, and Richard L. Rapson. Emotional Contagion. Cambridge: Cambridge University Press, 1994.

Hawker, Robert Stephen. Records of the Western Shore: Verse. Oxford: D. A. Talboys, 1832.

Echoes from Old Cornwall. London: Joseph Masters, 1846.

The Quest of the Sangraal: Chant, the First. Exeter: Printed for the author, 1864.

------ Cornish Ballads and Other Poems; Including a Second Edition of "The Quest of the Sangraal". Oxford and London: James Parker, 1869.

Healy, Elizabeth. In Search of Ireland's Holy Wells. Dublin: Wolfhound Press, 2001.

Hobsbawm, Eric, and Terence Ranger. (eds.) The Invention of Tradition. Cambridge: Cambridge University Press, 1983.

Holtorf, Cornelius, and Tim Schadla-Hall. 'Age as Artefact: On Archaeological Authenticity'. European Journal of Archaeology2, no. 2 (1999): 229-47.

Houlbrook, Ceri. 'The Mutability of Meaning: Contextualising the Cumbrian coin-tree'. Folklore 125, no. 1 (2014): 40-59.

-----. 'The Penny's Dropped: Renegotiating the Contemporary Coin Deposit'. Journal of Material Culture 20, no. 2 (2015a): 173-89.

.'The Wishing-Tree of Isle Maree'. In The Materiality of Magic: An Artifactual Investigation into Ritual Practices and Popular Beliefs, edited by Ceri Houlbrook and Natalie Armitage, 12342. Oxford: Oxbow, 2015b.

-----. 'Small Change: Economics and the British Coin-Tree'. Post-Medieval Archaeology 4, no. 1 (2015c): 114-30.

-----. “'Because Other People Have Done It": Coin-trees and the Aesthetics of Imitation'. Journal of Contemporary Archaeology 2, no. 2 (2015d): 243-61.

Hunt, Robert. Popular Romances of the West of England, or the Drolls, Traditions, and Superstitions of Old Cornwall. London: John Camden Hotten, 1908.

Hutton, Patrick. I Would Not Be Forgotten: The Life and Work of Robert Stephen Hawker, 1803-1875. Padstow: Tabb House, 2004.

John, Catherine Rachel. The Saints of Cornwall. Padstow: Lodenek Press, 1981.

Kneafsey, Moya. 'A Landscape of Memories: Heritage and Tourism in Mayo'. In Landscape, Heritage and Identity: Case Studies in Irish Ethnography, edited by Ullrich Kockel, 135-53. Liverpool: Liverpool University Press: 1995.

Landon, Letitia Elizabeth. 'St. Knighton's Kieve'. In The Poetical Works of Miss Landon, 291. Philadelphia: E. L. Caret and A. Hart, 1838.

Laws, Susan. 'Food for the Mind and Body'. Meyn Mamvro: Ancient Stones and Sacred Sites in Cornwell 18 (Summer 1992): 2. 
Lindsay, Peter H., and Donald A. Norman. Human Information Processing: An Introduction to Psychology. New York and London: Academic Press, 1972.

Lowenthal, David. The Past is a Foreign Country. Cambridge: Cambridge University Press, 1985.

Macdonald, Sharon. 'On 'Old Things': The Fetishization of Past Everyday Life'. In British Subjects: An Anthropology of Britain, edited by Nigel Rapport, 89-106. Oxford and New York: Berg, 2002.

Madge, Sidney Joseph. The 'Chapel,' Kieve and Gorge of 'Saint Nectan,' Trevillet Millcombe, Tintagel. N.p., 1950.

Melton, J. Gordon. The Encyclopedia of Religious Phenomena. Canton, MI: Visible Ink Press, 2008.

Morton, Andrew. Tree Heritage of Britain and Ireland. Marlborough: Airlife, 2004.

Muri, Gabriela. “'The World's Smallest Village”: Folk Culture and Tourism Development in an Alpine Context'. Traditional Dwellings and Settlements Review13, no. 1 (2001): 53-64.

Newall, Venetia J. 'The Adaptation of Folklore and Tradition'. Folklore 98, no. 2 (1987): 13151.

Orme, Nicholas. The Saints of Cornwall. Oxford: Oxford University Press, 2000.

Pacsco, Jo. 1992. 'Meanness and Magic in Cornwall'. Meyn Mamvro: Ancient Stones and Sacred Sites in Cornwall 19 (Autumn/Winter 1992): 4.

Pearce, Susan M. Museums, Objects and Collections: A Cultural Study. Leicester and London: Leicester University Press, 1992.

Penrose, Sefryn, ed. Images of Change: An Archaeology of England's Contemporary Landscape. Swindon: English Heritage, 2007.

Rattue, James. The Living Stream: Holy Wells in Historical Context. Woodbridge: Boydell Press, 1995.

Redding, Cyrus. An Illustrated Itinerary of the County of Cornwall. London: How \& Parsons, 1842.

Redgrove, Peter. 'The Glass Cottage'. The Hudson Review 28, no. 2 (1975): 173-226.

Rees, Elizabeth. Celtic Sites and their Saints: A Guidebook. London and New York: Burns \& Oates, 2003.

Roe, Helen M. 'Tales, Customs and Beliefs from Laoighis'. Béaloideas 9, no. 1 (1939): 2135.

Rountree, Kathryn. 'Performing the Divine: Neo-Pagan Pilgrimages and Embodiment at Sacred Sites'. Body \& Society 12 (2006): 95-115.

Silverman, Helaine. 'Touring Ancient Times: The Present and Presented Past in Contemporary Peru'. American Anthropologist 104, no. 3 (2002): 881-902.

Simon, Ben. 'Tree Traditions and Folklore from Northeast Ireland'. Arboricultural Journal24, no. 1 (2000): 15-40. 
Spooner, Brian. 'Weavers and Dealers: The Authenticity of an Oriental Carpet'. In The Social Life of Things: Commodities in Cultural Perspective, edited by Arjun Appadurai, 195-235. Cambridge: Cambridge University Press, 1986.

Wallis, Robert J., and Jenny Blain. 'Sites, Sacredness, and Stories: Interactions of Archaeology and Contemporary Paganism'. Folklore 114, no. 3 (2003): 307-21.

Zipes, Jack. Happily Ever After: Fairy Tales, Children, and the Culture Industry. New York and London: Routledge, 1997.

\section{Biographical Note}

With a PhD in Archaeology, attained from the University of Manchester, Ceri Houlbrook considers herself a historical ethnographer and folklore archaeologist, and is particularly interested in the material culture of popular customs and beliefs, both past and present. She is currently a Postdoctoral Research Assistant researching concealed deposits on the 'Inner Lives: Emotions, Identity and the Supernatural, 1300-1900' project at the University of Hertfordshire. 